\title{
The marine sedimentary environments of Kongsfjorden, Svalbard: an archive of polar environmental change
} \author{
Kari Skirbekk ${ }^{4}$, Beata Sternal ${ }^{4,12}$, Michel Boos ${ }^{11}$, Noortje Dijkstra ${ }^{4,11}$ \& Simon Troelstra ${ }^{11}$ \\ ${ }^{1}$ Norwegian Polar Institute, Tromsø, Norway; \\ ${ }^{2}$ Scottish Association for Marine Sciences, Scottish Marine Institute, Oban, UK; \\ ${ }^{3}$ University of Nantes, Nantes, France; \\ ${ }^{4}$ UiT - The Arctic University of Norway, Tromsø, Norway; \\ ${ }^{5}$ University Centre of Svalbard, Longyearbyen, Norway; \\ ${ }^{6}$ Department of Marine Geology, Institute of Oceanography, University of Gdańsk, Gdańsk, Poland; \\ ${ }^{7}$ Shirshov Institute of Oceanology, Russian Academy of Sciences, Moscow, Russia; \\ ${ }^{8}$ National Centre of Antarctic and Ocean Research, Vasco da Gama, Goa, India; \\ ${ }^{9}$ Department of Earth Sciences, Pisa University, Pisa, Italy; \\ ${ }^{10} \mathrm{Geological}$ Survey of Denmark and Greenland, Copenhagen, Denmark; \\ ${ }^{11}$ VU University Amsterdam, Amsterdam, The Netherlands; \\ ${ }^{12}$ Adam Mickiewicz University in Poznan, Poznań, Poland
}

Katrine Husum ${ }^{1}$, John A. Howe ${ }^{2}$, Agnes Baltzer ${ }^{3}$, Matthias Forwick ${ }^{4}$, Maria Jensen ${ }^{5}$, Patrycja Jernas ${ }^{4,6}$, Sergei Korsun 7 , Arto Miettinen ${ }^{1}$, Rahul Mohan ${ }^{8}$, Caterina Morigi ${ }^{9,10}$, Per Inge Myhre ${ }^{1}$, Maarten A. Prins ${ }^{11}$,

\begin{abstract}
Kongsfjorden, a fjord in north-western Svalbard, is characterized by large environmental gradients driven by meltwater processes along the margins of tidewater glaciers and the inflow of relatively warm Atlantic Water, the main heat source for the European Arctic. These factors make Kongsfjorden a key area to investigate changes in the polar climate-ocean-glacier system and to examine the resulting effects on the marine environment. The aim of this paper is to synthesize knowledge about the marine sedimentary environment in Kongsfjorden since the last deglaciation. Fjords act as natural sedimentary traps, archiving information about past and present environmental conditions and changes. Geological studies of Kongsfjorden have demonstrated a good potential for reconstructing palaeoenvironments and establishing baselines values for the natural climate changes in the Arctic. Palaeoceanographic reconstructions reveal rising water temperatures similar to modern temperatures ca. 12000 years ago. The extent of warm Atlantic Water entering the fjords influences processes at, and the stability of, the margins of the tidewater glaciers. Enhanced inflow may cause accelerated glacial melting that, in consequence, leads to an increase in the sediment flux from the glacial catchments into the fjord, as observed ca. 12000 years ago and at present. However, responses of sediment flux to modern environmental changes remain poorly understood, hence long-term and monitoring studies are needed to quantify and model the effects of climate warming on the sedimentary environment of Kongsfjorden.
\end{abstract}

\section{Keywords}

fjord; environment; geology; climate; sediments; deglaciation

\section{Correspondence}

Katrine Husum, Norwegian Polar Institute, Fram Centre, P.O. Box 6606 Langnes, NO-9296 Tromsø, Norway. E-mail katrine. husum@npolar.no

\section{Abbreviations \\ AMS: accelerator mass spectrometry; AW: Atlantic Water; BCE: before the Common Era; CE: Common Era; IRD: ice-rafted detritus; Kya: thousands of calendar years BP (unless otherwise stated); LGM: Last Glacial Maximum; LIA: Little Ice Age; MCA: Medieval Climate Anomaly}

\section{Introduction}

Modern climate change has resulted in elevated oceanic water temperatures in the Arctic, with the consequence of reducing summer sea-ice extent and accelerating the retreat of ice sheets (e.g., Richter-Menge et al. 2017). This can greatly affect the finely balanced environment of the region, causing, for example, ecological regime shifts in marine benthos (Kortsch et al. 2012) or changes of kelp biomass (Bartsch et al. 2016). It may also inhibit the seasonal production of local sea ice and add freshwater into coastal and oceanic regions (e.g., Carmack et al. 2015). As a result, there is an urgent need to improve our understanding of the short- and long-term effects, and 
feedbacks, of polar climate change. Arctic fjords can provide valuable information on this, and previous investigations of Svalbard fjords have demonstrated that these possess sediment archives that allow us to reconstruct environmental changes and establish baseline values for change in the Arctic (e.g., Hald \& Korsun 2008; Forwick \& Vorren 2009; Rasmussen et al. 2012; Jernas et al. 2013; Pawłowska et al. 2016). The main heat source for the European Arctic is the northward flow of warm, saline and nutrient-rich AW via the North Atlantic Current (Aagaard \& Carmack 1994; Rudels et al. 1994). Through the supply of heat, this current has a major influence on the environmental conditions in the Arctic, and hence, the variability of AW is a principle driver of environmental change in western Svalbard.

Kongsfjorden is part of the Kongsfjorden-Krossfjorden system (Fig. 1) in north-western Svalbard, which is directly influenced by AW entering the fjords (e.g., Svendsen et al. 2002; Sundfjord et al. 2017; Jernas et al. 2018). The supply of AW into the fjords may lead to increased calving of tidewater glaciers and occasionally to accelerated glacial retreat and more meltwater in the fjords (e.g., Luckman et al. 2015). Previous studies have shown an increase in heat transport to the Arctic Ocean since 1995 (e.g., Beszczynska-Möller et al. 2012; Nilsen et al. 2016; Polyakov et al. 2017), and an increased advection of AW along western Svalbard was observed in 2005-06 (Cottier et al. 2007). This resulted in a temperature and

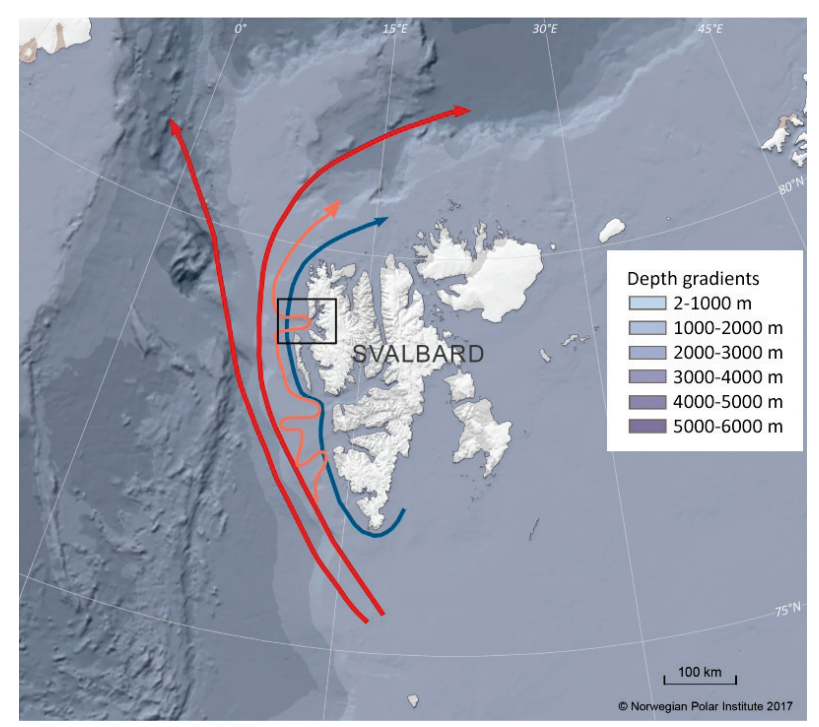

Fig. 1 Index map showing Svalbard and dominating current systems. The red lines are branches of the West Spitsbergen Current. The pink line is the Spitsbergen Trough Current. The blue line is the Spitsbergen Polar Current. Modified from Nielsen et al. (2016). The black square shows the location of the Kongsfjorden-Krossfjorden system, as shown in Fig. 3. salinity maximum of AW in the Fram Strait region in 2006 followed by a rapid decrease (Walczowski et al. 2012). The temperature increase of AW in 2006 seems to be unprecedented when compared to reconstructed ocean temperatures for the last two millennia (Spielhagen et al. 2011). Studies of palaeoproxy records by Jernas et al. (2013) have shown how fluctuations in the benthic foraminiferal fauna seem to be linked to changes in ocean temperatures during the last two millennia, presumably reflecting variations of AW inflow into Kongsfjorden (Fig. 1). These reconstructions included the LIA and MCA, two prominent climate anomalies of the last millennium occurring in the North Atlantic region (e.g., Lamb 1977). The transition between these periods was also reflected in the higher production of planktonic foraminifera and an overall change in species composition on the continental shelf offshore north-western Svalbard (Spielhagen et al. 2011). Ślubowska et al. (2005) revealed a similar signature of the Early Holocene warming on the continental margins around Svalbard. This is considered a general pattern for the European Arctic and north-eastern Atlantic region (e.g., Hald et al. 2007; Aagaard-Sørensen et al. 2010; Aagaard-Sørensen et al. 2014; Werner et al. 2016) and in fjords on the western coast of Spitsbergen (e.g., Hald et al. 2004; Forwick \& Vorren 2009; Risebrobakken et al. 2011; Rasmussen et al. 2014). The rising ocean temperatures and waning sea-ice extent that occurred during the early Holocene are similar to the present-day observations. By analysing the regional temporal and spatial patterns of climate responses to this past warm period, we may demonstrate that the early Holocene may serve as an analogue for the current and future development of the ongoing warming in the Arctic.

The inflow of AW to the Kongsfjorden-Krossfjorden system also greatly influences the tidewater glaciers in the fjord system and may accelerate glacial melting (e.g., Luckman et al. 2015). A direct consequence of this is an increase in the sediment flux from the glacial catchments into the fjord system (e.g., Szczuciński et al. 2009). The enhanced input of glacigenic sediments has an impact on light penetration in the water column, temperatures and salinity. These changes in hydrography, glacial meltwater flux and sediment flux affect the benthic ecosystem, with impacts on all trophic levels (e.g., Wlodarska-Kowalczuk et al. 2005).

The Kongsfjorden-Krossfjorden system has been the focus of major scientific attention, resulting in many studies on a variety of topics. However, comprehensive reviews have focused mostly on modern oceanographic and physical conditions (Svendsen et al. 2002; Hop et al. 2006) as well as marine biology and ecosystems in the Kongsfjorden-Krossfjorden system (Hop et al. 2002; Hop et al. 2006; Wiencke \& Hop 2016). Here, we present a review of the current knowledge of the present and 
past marine sedimentary environment in Kongsfjorden. The review ranges from peak glacial conditions during the LGM through the Holocene, with peak warm conditions showing natural ranges for change within Arctic glaciomarine environments.

\section{Regional setting of the Kongsfjorden- Krossfjorden system}

The archipelago of Svalbard is surrounded by the Arctic Ocean to the north, the Barents Sea to the south and east, and Fram Strait to the west. The KongsfjordenKrossfjorden system is a fjord system located between $78^{\circ} 40^{\prime}$ and $77^{\circ} 30^{\prime} \mathrm{N}$ and $11^{\circ} 03^{\prime}$ and $13^{\circ} 06^{\prime} \mathrm{E}$ that incises the north-western coastline of Spitsbergen, the largest island of the archipelago (Fig. 1). It continues across the continental shelf as a cross-shelf trough, Kongsfjordrenna (Howe et al. 2003; Ottesen et al. 2007; Dowdeswell et al. 2016).

The large-scale bathymetry of the KongsfjordenKrossfjorden system is a result of the surrounding bedrock geology and glacial processes (Elverhøi et al. 1983; Sexton et al. 1992; Howe et al. 2003; MacLachlan et al. 2010; Streuff et al. 2015). The region surrounding Kongsfjorden and Krossfjorden includes the tectonic boundary between the Tertiary Fold and Thrust Belt to the south-west and the older, predominantly metamorphic, Northwestern Basement Province to the north-east (Bergh et al. 2000). The axis of Kongsfjorden is oriented parallel to the thrust front. North of Kongsfjorden, the bedrock consists of medium-grade metamorphic marbles, mica-schists and quartzites of Proterozoic age. The islands of Blomstrandhalvøya and Lovénøyane are composed of marbles with Devonian-age Old Red Sandstone in isolated outcrops (Fig. 2). Devonian sedimentary rocks, for example, "Old Red Sandstones", also occur in the region east of Kongsfjorden, where they overlay basement units belonging to the Northwestern Basement Province. The land area south of Kongsfjorden consists of sedimentary rocks of Late Palaeozoic and Palaeogene age, and low-metamorphic Proterozoic phyllite, marble and schists of the Kongsvegen Group (Dallmann 2015). At Ny-Ålesund, the bedrock comprises Palaeogene coal, conglomerates, sandstones and shales of the Ny-Ålesund Subgroup, also part of the Tertiary Fold and Thrust Belt (Dallmann 2015).

Kongsfjorden is $20 \mathrm{~km}$ long, with a variable width of 4-10 km. A submarine sill separates Kongsfjorden from the trough Kongsfjordrenna (Fig. 3). The sill has the form of a submarine spur extending from the northern coast at the mouth of Kongsfjorden. The water depth of the sill increases from less than $50 \mathrm{~m}$ in the northern parts of the trough to 250-300 m (Howe et al. 2003), so it is

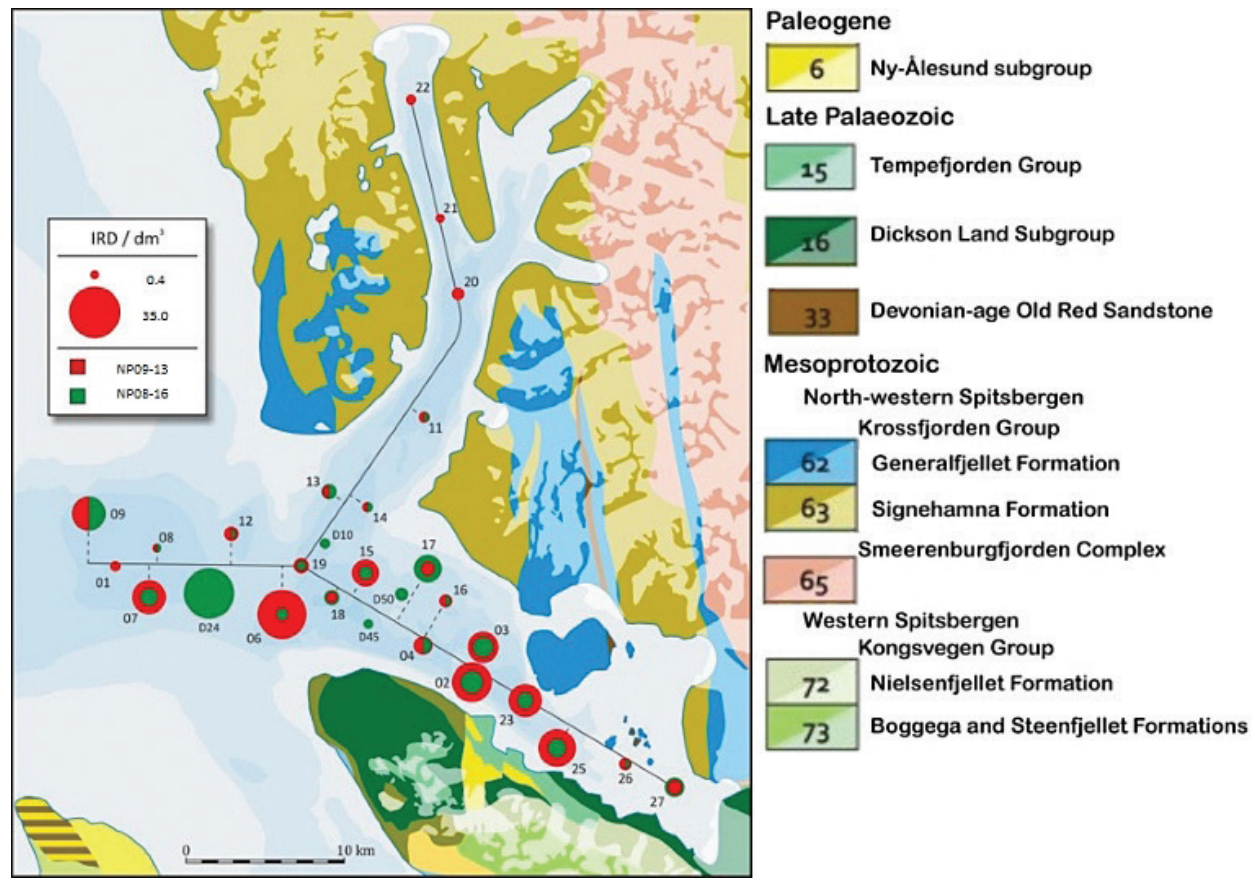

Fig. 2 IRD concentration in surface sediment samples from the Kongsfjorden-Krossfjorden system. Samples that were collected in 2008 (cruise NP0816) are marked with green and samples from 2009 (cruise NP0 9-13) are marked with red. Modified from Dallmann (2015). 


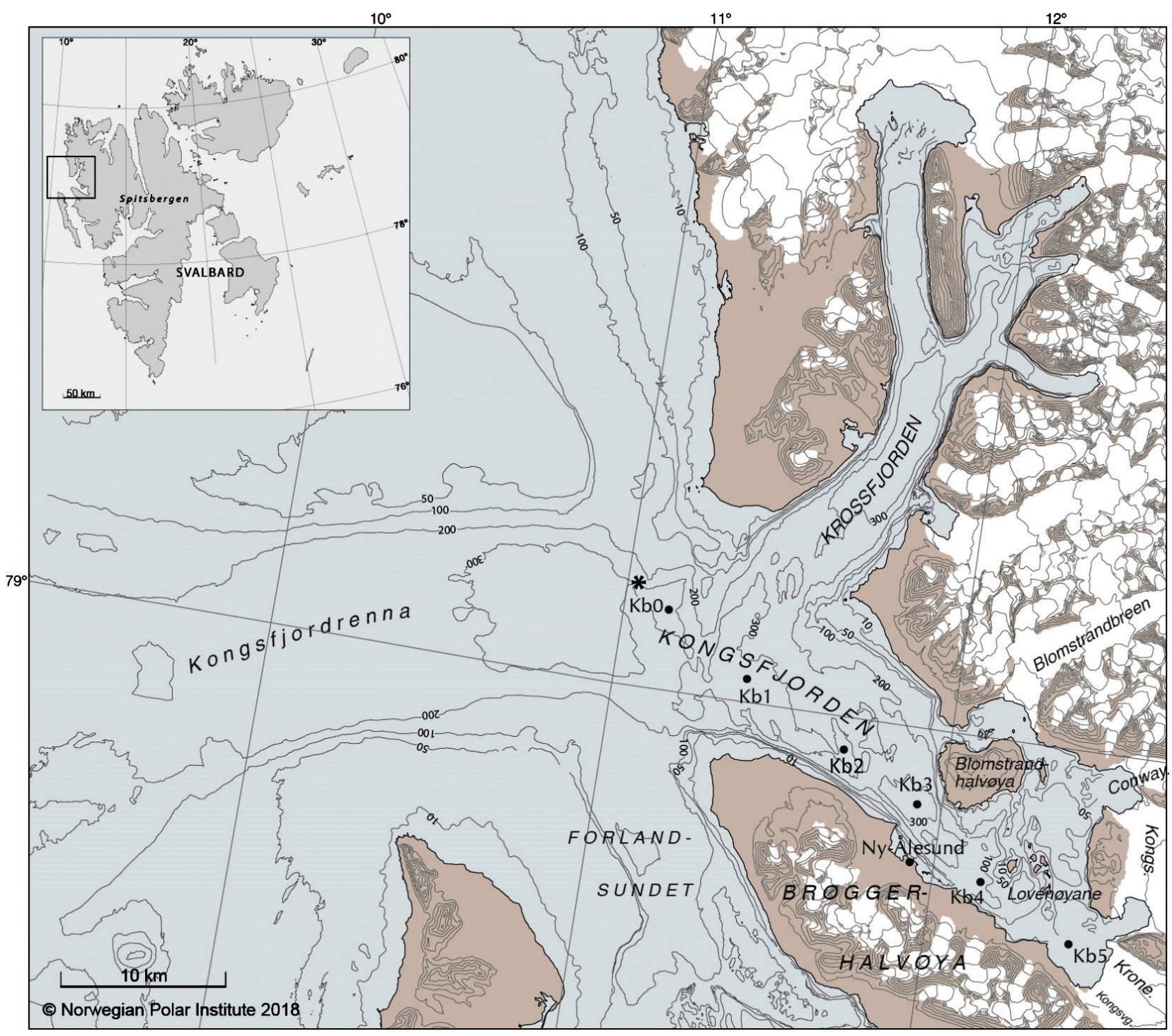

Fig. 3 Bathymetric map showing Kongsfjorden and surroundings. Depths are given in metres. Oceanographic stations Kb0-Kb5 are indicated with black dots. The asterisk shows the location of sediment cores NP05-21 GC and NP05-21MC (Skirbekk et al. 2010; Jernas et al. 2013). Names of some of the tidewater glaciers have been abbreviated as follows: "Conway" is Conwaybreen, "Kongs" is Kongsbreen, "Krone" is Kronebreen and "Kongsvg" is Kongsvegen.

only a modest barrier to water mass exchange between the fjord and the open shelf (e.g., Svendsen et al. 2002). A deep basin of $394 \mathrm{~m}$ water depth occurs in the outer part of Kongsfjorden, close to the fjord mouth. Inside the fjord, towards the peninsula Blomstrandhalvøya, water depth decreases to less than $100 \mathrm{~m}$ (Howe et al. 2003). It remains shallower than $100 \mathrm{~m}$ in the inner fjord part. Towards the Lovénøyane islands, as well as towards the glacier front, water depths decrease further to less than $50 \mathrm{~m}$ (Fig. 3).

Krossfjorden separates from Kongsfjorden at the fjord mouth extending to the north (Fig. 3). The fjord is $30 \mathrm{~km}$ long and has a width of $3-6 \mathrm{~km}$. An outer sill of 250-300 m water depth separates Krossfjorden from Kongsfjorden (Sexton et al. 1992). The outer part of Krossfjorden is up to $374 \mathrm{~m}$ deep (MacLachlan et al. 2010). Towards the north, Krossfjorden bifurcates into two minor fjords (Fig. 3). The water depths in these two inner fjords are ca. 250-100 m (Sexton et al. 1992).

Two water masses, AW and Arctic Water, dominate the hydrography in Kongsfjordrenna (Cottier et al. 2005). Relatively warm and saline AW flows northward in the West Spitsbergen Current along the West Spitsbergen Margin, transporting heat northward (Schauer et al. 
2004) (Fig. 1). AW also flows onto the shelf and penetrates into troughs as the Spitsbergen Trough Current (Nilsen et al. 2016). The Spitsbergen Polar Currentflowing parallel to the West Spitsbergen Current and Spitsbergen Trough Current and closer to the coasttransports colder and less saline Arctic Water originating from the Barents Sea and Storfjorden area (Nilsen et al. 2016) (Fig. 1). AW enters Kongsfjorden when the front between AW and Arctic Water is unstable, allowing AW to spread onto the shelf and into the trough. Factors affecting the stability of the front include atmospheric forcing (e.g., wind-driven advection [Cottier et al. 2007]) or density/pressure changes of the water masses (e.g., Svendsen et al. 2002; Tverberg \& Nøst 2009; Inall et al. 2015; Nilsen et al. 2016). AW inflow to Kongsfjorden is driven by different factors such as freshwater runoff, surface heat fluxes, vertical mixing and wind forcing within the fjord (Cottier et al. 2005). During spring, solar radiation melts the sea ice and warms the surface water layer, making the upper water masses less dense and increasing the stratification (Fig. 4). The upper fresh water masses flow out of the fjord, and in return, AW and coastal water of intermediate salinity flow into Kongsfjorden (Svendsen et al. 2002). AW inflows occur all year round, and it may be substantial during winter (Cottier et al. 2007; Berge et al. 2015). A recent study of the AW inflow in Kongsfjorden (Sundfjord et al. 2017) has shown that local winds strongly influence the inflow in summers and winters, whereas estuarine circulation driven by glacial meltwater only occurs during summer and is less important. In autumn and winter, the surface water masses cool and sea ice is formed and brine is released (Cottier et al. 2005; Cottier et al. 2010; Sundfjord et al. 2017). These processes increase the density of the upper water masses and by vertical mixing the water column is renewed (e.g., Cottier et al. 2010). It has to be noted that both the extent and thickness of sea ice in Kongsfjorden have diminished since 2006 (Gerland \& Renner 2007).

\section{Material and methods}

Bathymetry and submarine landforms have been mapped using swath-bathymetry data (Howe et al. 2003; Ottesen et al. 2007; MacLachlan et al. 2010; Forwick et al. 2015; Streuff et al. 2015) and single-beam echo sounder data (Ottesen et al. 2007), in addition to sub-bottom profiler data (Elverhøi et al. 1983; Howe et al. 2003; MacLachlan et al. 2010; Trusel et al. 2010; Kehrl et al. 2011; Streuff et al. 2015). Modern glaciomarine sedimentation processes have been investigated using sediment traps, a SeaTech transmissometer and an optical backscatter device (Trusel et al. 2010) or broadband acoustic Doppler current profiler (Meslard et al. 2018), together with water samples, to quantify concentrations of suspended particulate matter. Other lithological investigations and/or palaeoceanographic reconstructions are based on gravity cores (Howe et al. 2003; Skirbekk et al. 2010; Jernas et al. 2013; Rasmussen et al. 2014; Streuff et al. 2015), box cores (Elverhøi et al. 1980; Elverhøi et al. 1983; Kumar et al. 2018) and multi-cores (Jernas et al. 2013). New data on grain size distribution $(<2 \mathrm{~mm})$ in the surface sediments (multi corer samples $0-1 \mathrm{~cm}$ ) have been obtained with laser-diffraction particle size analysis using a Fritsch Analysette A22 instrument (Dijkstra 2009). Existing data from Kumar et al. (2018) from box cores were obtained using a CILAS 1090 Laser Particle Size Analyser, whereas Streuff et al. (2015) used a Beckman Coulter LS13320 Laser Diffraction Particle Size Analyser on samples from gravity cores. For this study, new data presenting rock fragments $>4 \mathrm{~mm}$ in size from multi-cores have been analysed to quantify the coarse IRD concentration in the upper $\leq 70 \mathrm{~cm}$ of the sediments (Dijkstra 2009; Boos 2012). The samples were sieved at the $>4 \mathrm{~mm}$ size fraction, and all grains were counted to get actual grain counts per unit volume $\left(\mathrm{IRD} / \mathrm{dm}^{3}\right)$. Palaeoceanographic reconstructions are based on benthic and planktic foraminiferal faunas, transfer-function calculations of sub-surface and bottom water temperatures in addition to stable isotope measurements of $\delta^{18} \mathrm{O}$ and $\delta^{13} \mathrm{C}$ of the calcareous foraminiferal shells (e.g., Rasmussen et al. 2014 and references therein). Chronologies were established from AMS ${ }^{14} \mathrm{C}$ and ${ }^{210} \mathrm{~Pb}$ datings (e.g., Skirbekk et al. 2010; Jernas et al. 2013; Streuff et al. 2015). AMS ${ }^{14} \mathrm{C}$ dates were calibrated to calendar years using the calibration programmes OxCal (Ramsey 2009) or CALIB (Stuiver \& Reimer 1993) with the marine calibration curve Marine09 (Reimer et al. 2009). A regional reservoir age $(\Delta \mathrm{R})$ of $105 \pm 24$ years (Mangerud et al. 2006) was applied for the calibration of the ${ }^{14} \mathrm{C}$ dates.

\section{Glacier dynamics and marine sedimentary processes since the LGM}

During the LGM most of north-west Svalbard, except for some nunataks, was covered by the north-western parts of the Svalbard Barents Sea Ice Sheet (e.g., Landvik et al. 2003). Parts of the ice sheet were drained by fast flowing ice streams through fjords and troughs across the shelf to the shelf break. There were also areas with less active ice movement (Landvik et al. 2005; Ottesen \& Dowdeswell 2009; Landvik et al. 2013). The ice sheet reached its LGM extent between ca. 24 and 23.5 Kya (Jessen et al. 2010). Ottesen et al. (2005) identified mega-scale glacial lineations in the Kongsfjordrenna, suggesting 
that Kongsfjorden acted as a conduit for a fast-flowing ice stream during the last glacial (Landvik et al. 2005; Ottesen et al. 2007). The deglaciation began at ca. 20.5 Kya at the shelf edge, and the north-western part of the fjord mouth was deglaciated before 14.4 Kya (Jessen et al. 2010; Henriksen et al. 2014).

Transverse ridges (moraines) and grounding-zone wedges in the Kongsfjordrenna and in Kongsfjorden suggest that the ice front halted and/or re-advanced repeatedly during the deglaciation (e.g., Howe et al. 2003; Ottesen et al. 2007; Dowdeswell et al. 2016). MacLachlan et al. (2010) suggested that some moraines might be annual retreat moraines. The deglacial retreat to the early Holocene minimum position terminated around $10.2 \mathrm{Kya} / 9440 \pm$ $130{ }^{14} \mathrm{C}$ years before the present (Lehman \& Forman 1992). During and after the deglacial retreat, sediments were deposited from suspension settling and ice rafting resulting in accumulations of massive mud up to $20 \mathrm{~m}$ in thickness, with scattered IRD in the outer and central basins of Kongsfjorden (e.g., Elverhøi et al. 1980; Elverhøi et al. 1983; Howe et al. 2003). Sediment reworking occurred repeatedly, through slope failures on the slopes in the central and distal fjord giving rise to debris lobes (e.g., Howe et al. 2003; Forwick et al. 2015), as well as from reworking of proglacial deposits during glacier advances (Fig. 5), either due to climatic cooling during the LIA or due to glacial surges (Hagen et al. 1993; Streuff et al. 2015).

Many ice-field outlets on Svalbard are surge-type glaciers (e.g., Farnsworth et al. 2016), and within Kongsfjorden three glaciers-Blomstrandbreen, Kronebreen and Kongsvegen-have surged during the last ca. 150 years (Hagen et al. 1993; Streuff et al. 2015). The seafloor of the inner part of Kongsfjorden reveals characteristic landform assemblages of moraines, crevasse-squeeze ridges and glacial lineations (Fig. 5). They reflect different stages of glacier advance, stagnation or retreat due to climatic forcing or surges caused by internal glacier dynamic (e.g., Forwick et al. 2015 and references therein).

\section{Modern sedimentation and sediment accumulation rates}

Sediment supply in glaciated fjords can occur by a variety of processes. The dominant process in the fjord today is settling of fine-grained sediments from meltwater plumes and ice rafting (e.g., Elverhøi et al. 1980; Elverhøi et al. 1983; Howe et al. 2005; Streuff et al. 2015; Meslard et al. 2018). Tidewater glaciers can supply sediments from clay to boulders, but clay and silt are typically transported over large distances in Kongsfjorden (e.g., Forwick et al. 2015). Rivers are also a dominant source of sediment supply to the fjord, transporting mainly fine-grained sediments (Forwick et al. 2015). Geomorphological changes along the south coast also document terrestrial sediment input along the fjord shore (Bourriquen et al. 2016). Previously unpublished studies analysing grain size distributions of the surface sediments ( $<2 \mathrm{~mm}$ ) show that Kongsfjorden, Krossfjorden and Kongsfjordrenna are characterized by very similar fine-grained, bi- or trimodal grain-size distributions (Fig. 6). The distributions show the dominance of suspension settling from meltwater plumes (modes at ca. 2-3 $\mu \mathrm{m}$ and 10-20 $\mu \mathrm{m}$ ) in addition to a secondary mode at $>100 \mu \mathrm{m}$, most likely reflecting material transported and deposited from icebergs or sea ice, the so-called IRD. Studies by Kumar et al. (2018) have also found a bi-modal grain size distribution in surface sediments in the Kongsfjorden-Krossfjorden system, reflecting these two processes of sedimentary deposition. The coarse-grained IRD content (rock fragments $>4 \mathrm{~mm}$ ) reveals large spatial differences in sediment composition within the Kongsfjorden-Krossfjorden system (Figs. 2, 6). IRD content is low in inner Kongsfjorden and throughout

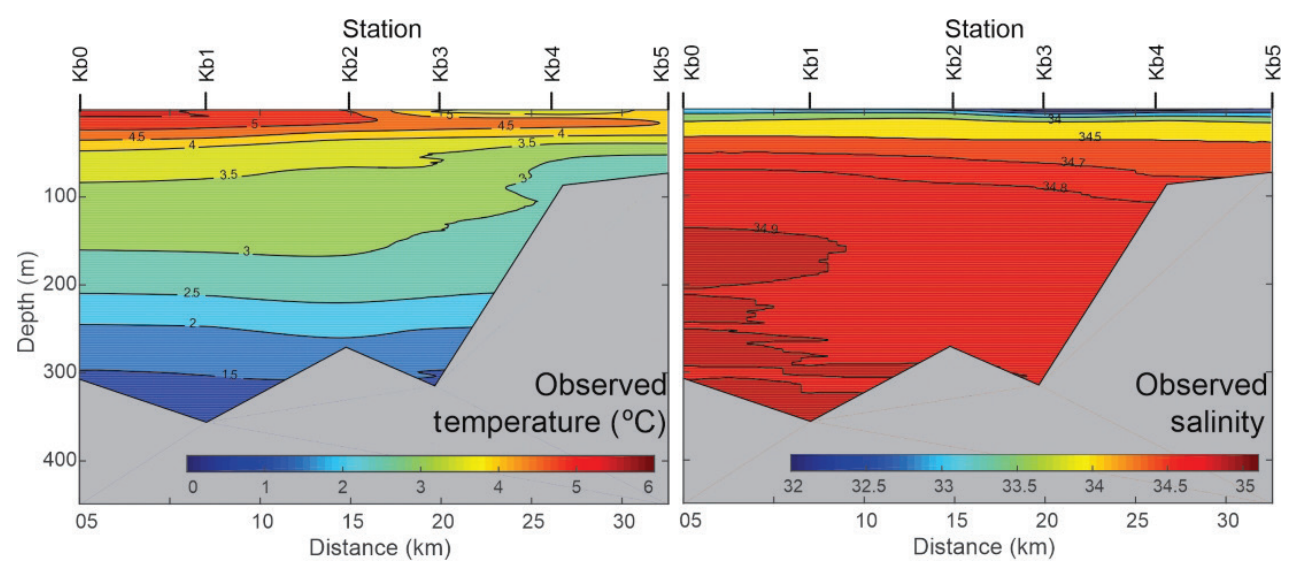

Fig. 4 A profile of summer temperature and salinity along the fjord. The positions of the stations are shown in Fig. 3. Modified from Sundfjord et al. (2017). 


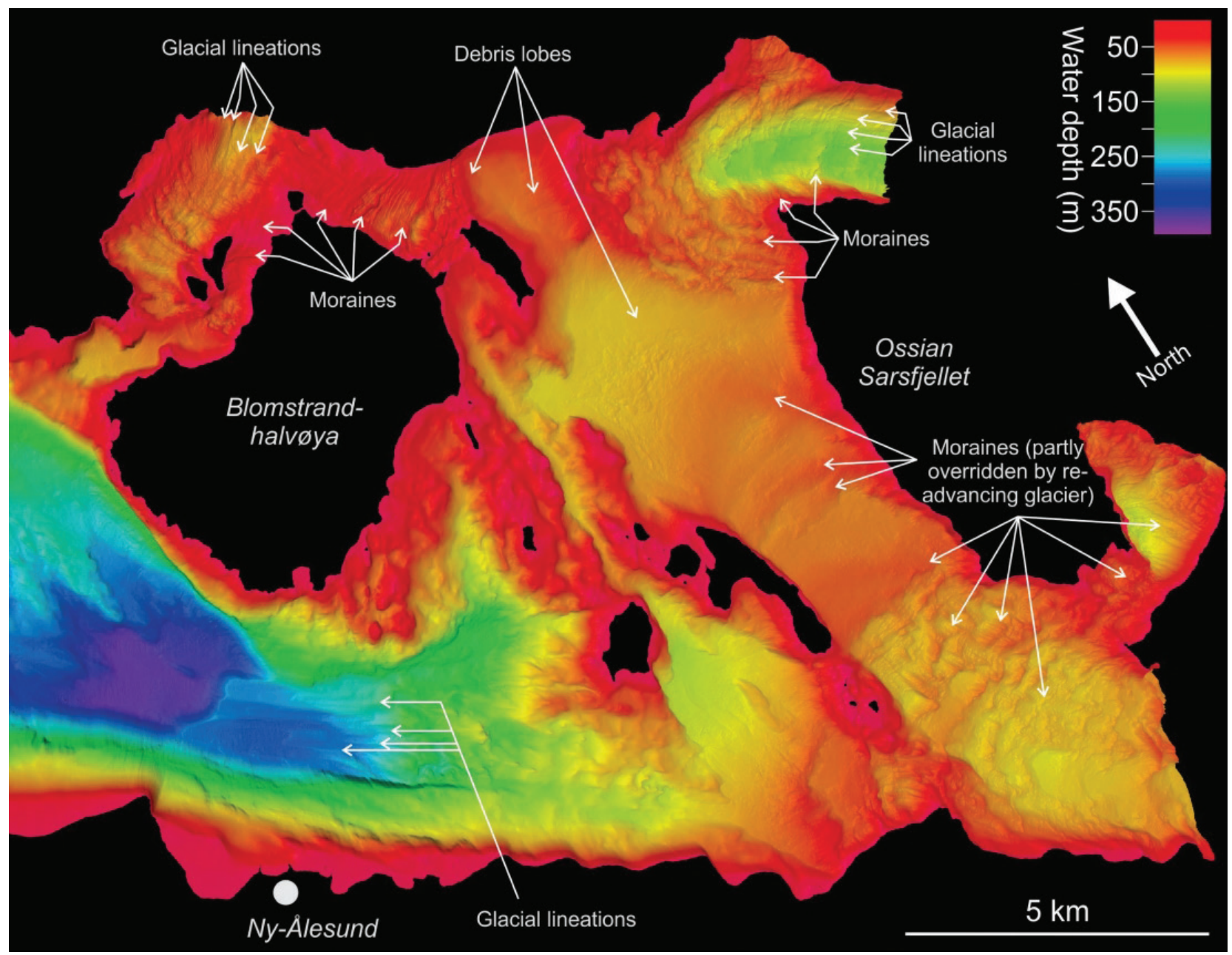

Fig. 5 Swath bathymetry of inner Kongsfjorden revealing glacial landforms reflecting repeated glacier halts and readvances (after Forwick et al. 2015; Streuff et al. 2015). Data provided by the Norwegian Hydrographic Service.

Krossfjorden, whereas it is high in the central part of Kongsfjorden and at some locations in Kongsfjordrenna (Fig. 2). The spatial difference in IRD amount is most likely caused by several factors. They include increased dilution by meltwater plume fines resulting in low IRD content in inner Kongsfjorden and/or that IRD is transported further offshore with icebergs than clay- and silt-sized sediment with meltwater plumes, in addition to differences in bedrock geology in the glacial drainage basins.

Elverhøi et al. (1983) have estimated that the average sediment accumulation rate was $0.1-1.0 \mathrm{~mm} /$ year for the central part of Kongsfjorden since the last deglaciation and 50-100 mm/year for the inner fjord basin since the more recent glacier retreat since the LIA. Streuff et al. (2015) estimated the sediment accumulation rate to be $300 \mathrm{~mm} /$ year in the innermost part of Kongsfjorden, $2.5 \mathrm{~km}$ from the glacier front, immediately after a surge of Kronebreen reached its maximum position in 1948. However, it dropped rapidly to ca. $18 \mathrm{~mm} /$ year as the glacier front retreated. Modern sediment accumulation rate values just in front of the glaciers Kongsvegen and Kronebreen are calculated to be $>1 \mathrm{~m}$ /year (Trusel et al. 2010; Kehrl et al. 2011). It has been estimated that the Kronebreen-Kongsvegen glaciers discharge ca. 2.5 million tonnes of sediments during the summer melting period (Meslard et al. 2018).

The evolution of the coast in Kongsfjorden can be linked to the retreat of terrestrial glaciers, and the development of the prodeltas (submarine parts of the deltas), representing a significant volume of sediments deposited directly into the fjord (Bourriquen et al. 2016). However, sediment supply from prodeltas is rarely taken into account, as they are located close to the land and mainly between 5 and $25 \mathrm{~m}$ of water depth, providing challenging conditions for mapping. The quantification of the evolution of the submarine 

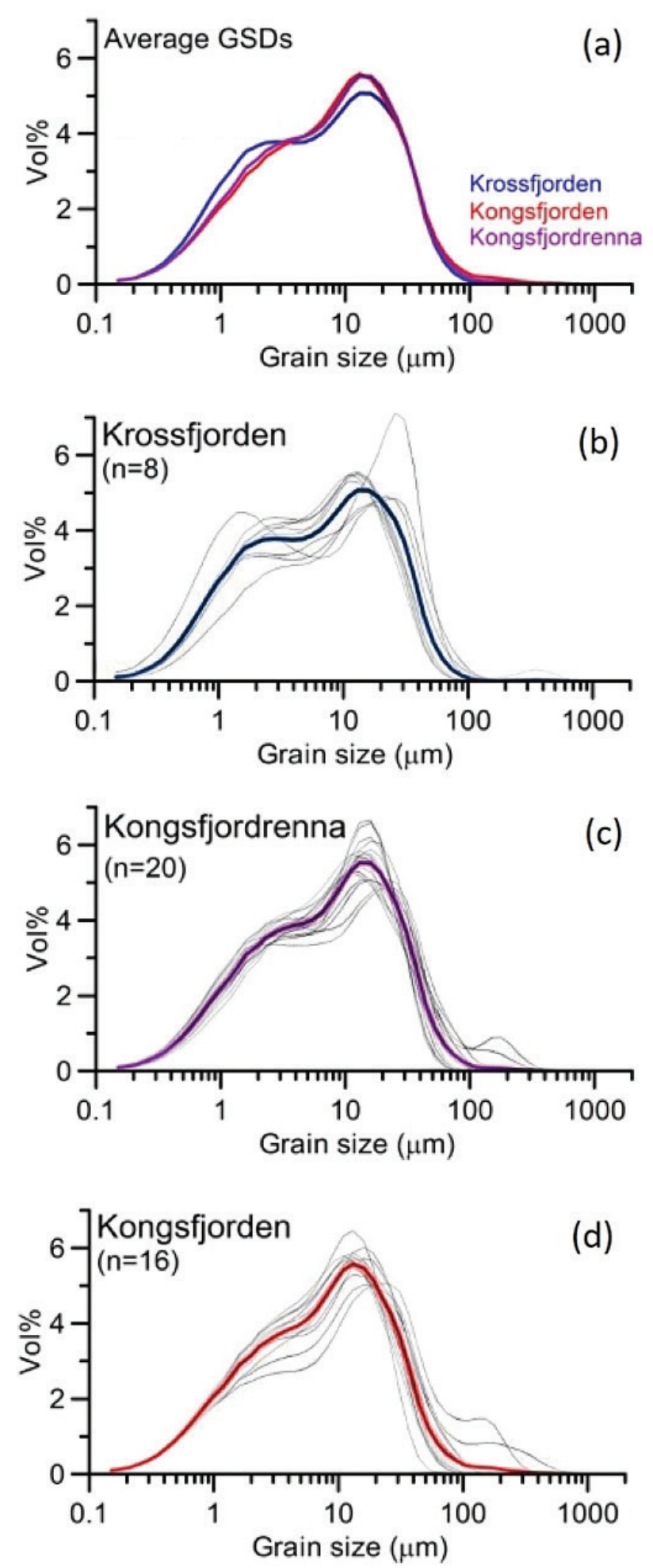

Fig. 6 (a) Mean grain-size distributions (GSD) [of surface sediment samples from the Kongsfjorden-Krossfjorden system. Grain-size distributions (thin grey lines) and their mean (bold lines) of surface sediment samples from (b) Krossfjorden, (c) Kongsfjordrenna and (d) Kongsfjorden. The locations of the sampling stations are shown in Fig. 2. prodeltas has been estimated from side-scan sonar mosaics, revealing that their extent expanded by ca. $40000 \mathrm{~m}^{2}$ from 2009 to 2012 (Fig. 7; Bourriquen et al. 2016). The related increased volume of fine-grained sediment supply to the fjord, resulting in expanding prodeltas, probably also gave rise to an increase of the fjord turbidity. An overall progradation of the coast can be observed from 1966 to 2012 (Fig. 7). Some parts of the coastline have retreated, yet most of the coastlines have prograded within specific areas linked to the location of the prodeltas (Bourriquen et al. 2016).

\section{Palaeoceanographic changes since the LGM}

AW reached Svalbard only for shorter intervals during the last glacial (14.5-19.5 Kуa, 22.5-29 Kуa, 34.5-37 Куа, 42.5-47.5 Kуa, са. 49-51 Kya, ca. 54-60 Kya), correlating temporarily with Heinrich events supplying moisture and precipitation for ice sheet growth in the region (Hebbeln et al. 1994; Dokken \& Hald 1996; Kremer et al. 2018). Since the deglaciation, there has been a continuous inflow of AW northwards along the West Spitsbergen Margin and through the Barents Sea into the Arctic Ocean (e.g., Aagaard-Sørensen et al. 2010; Risebrobakken et al. 2010). The first inflow of AW into Kongsfjorden occurred after $11.8 \mathrm{Kya}$, which coincides with a period of glacial retreat to the early Holocene minimum position in the fjord as inferred by a high IRD flux (Skirbekk et al. 2010). However, these warmer conditions were shortly interrupted during the Preboreal Oscillation around 11.3 Kya. The inflow of AW in the eastern Nordic seas was at its maximum at $10 \mathrm{Ky}$ (Risebrobakken et al. 2011), and a strong influence of AW is recorded at the mouth of Kongsfjorden from 10.6 to 7.0 Kya (Table 1; Skirbekk et al. 2010). This is reflected, for example, by a high production of benthic foraminifera in sediment core NP052lGC (Fig. 3) and a high frequency of Buccella species that are characteristic of high productivity and low IRD flux (Fig. 8; Skirbekk et al. 2010). Further investigations by Rasmussen et al. (2014) using planktic and benthic foraminiferal species and stable oxygen measurements $\left(\delta^{18} \mathrm{O}, \delta^{13} \mathrm{C}\right)$ found that AW on the west Spitsbergen margin displayed the highest sea-surface and bottom water temperatures from 11.5 to 8.2 Kya (except for the Preboreal Oscillation). However, transfer functions (planktic foraminifera) indicate that the subsurface water masses were the warmest between ca. 9 and 6 Kya. The comparison of this water-temperature reconstruction with relative palaeocurrent speed reconstructions using sortable silt from the south-western Spitsbergen shelf suggests a maximum heat flux at 9.0-7.5 Kya (Sternal et al. 2014). Subsequently, both subsurface and bottom water masses cooled, reaching minimum temperatures between 


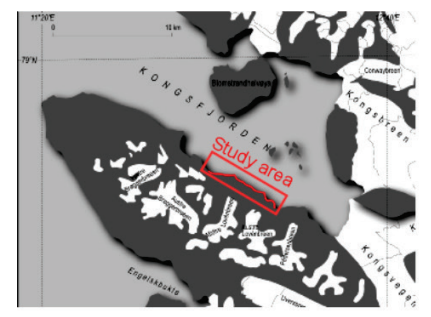

Prodelta 3: $\quad 68000 \mathrm{~m}^{2}-60300 \mathrm{~m}^{2}$

Prodelta 4: $15542 \mathrm{~m}^{2}-24300 \mathrm{~m}^{2}$

Prodelta $5 \& 6: 106500 m^{2}-135500 m^{2}$
Prodeltas evolution (m) from 2009 to 2012 calculated from side scan sonar mosaics

(a)

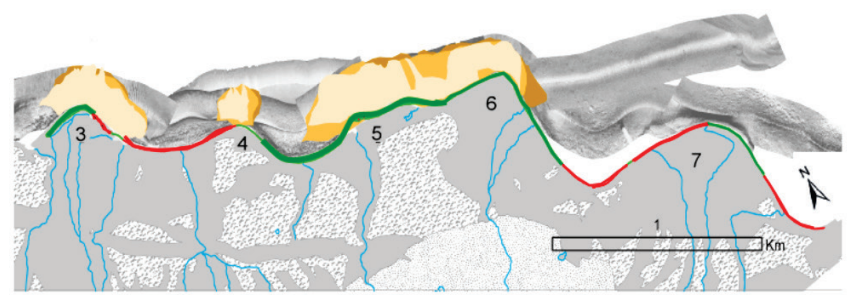

(b)

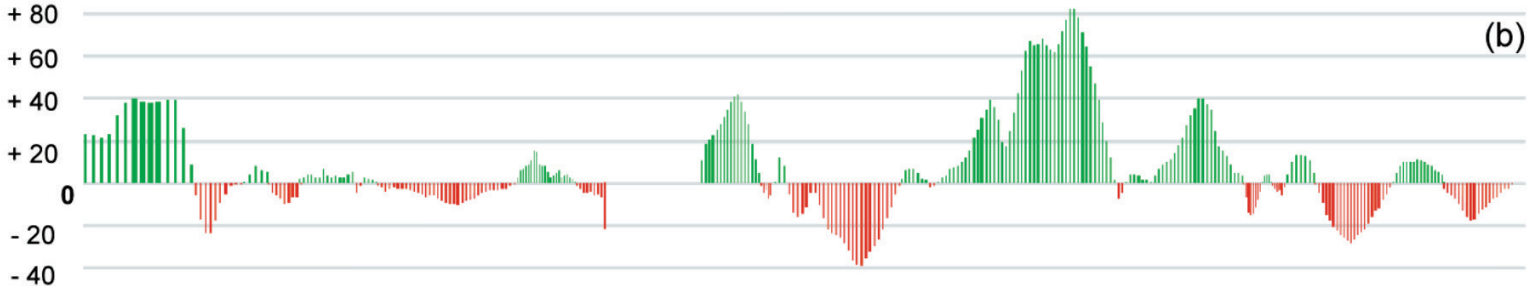
Coastal evolution $(\mathrm{m})$
from 1966 to 2016
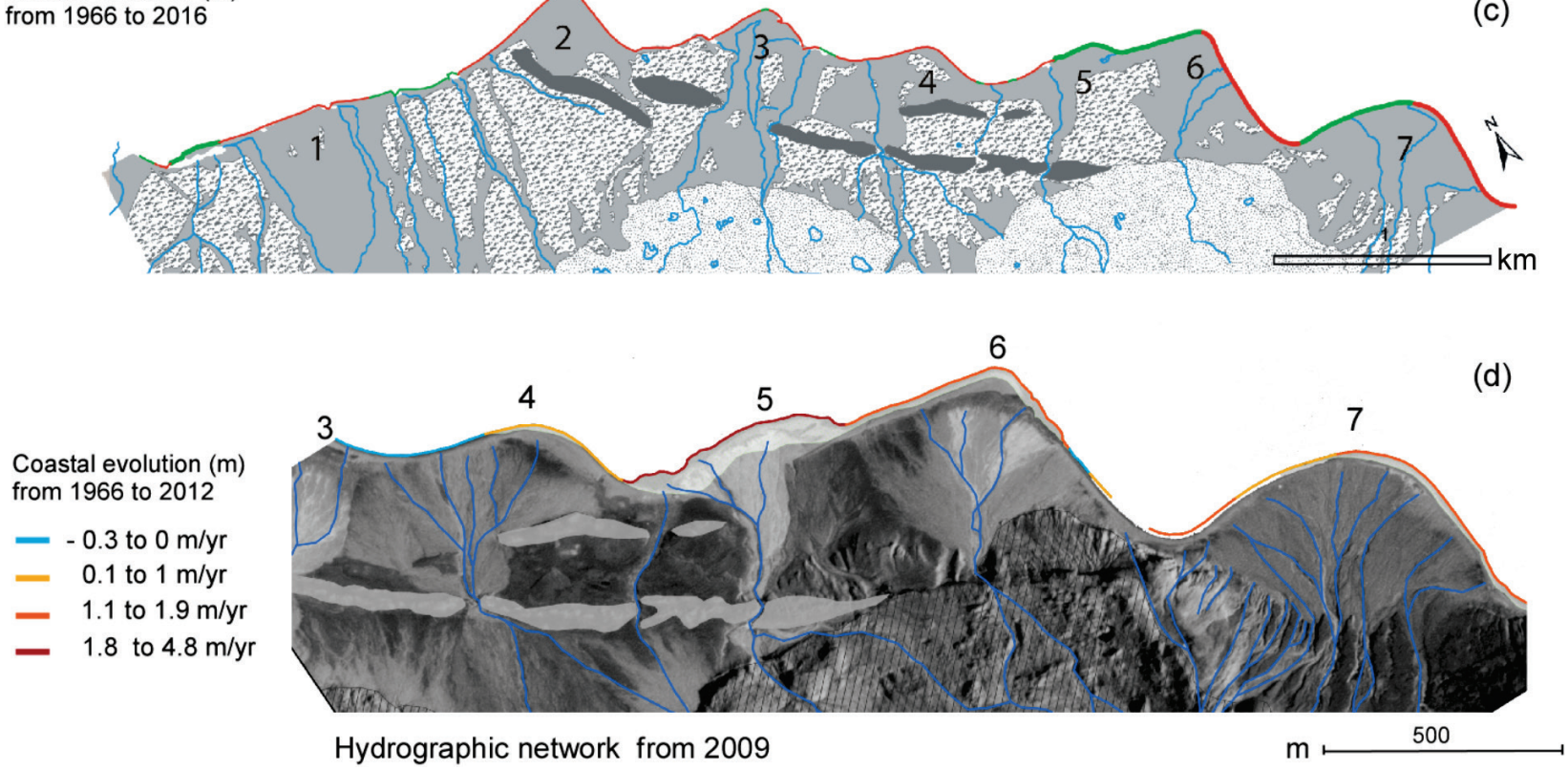

Fig. 7 (a) The evolution of the prodeltas (numbered from 3 to 7) with regard to area ( $\mathrm{m}^{2}$ ) in addition to advance (green line) and decrease (red line). (b) The quantitative values of the coastal evolution from 1966 to 2016 (m). Advance is shown with positive values and green bars. Decrease is indicated with negative values and red bars. (c) The hydrographic network of the area in 2012. (d) The rate of the coastal evolution (m/year). Modified from Bourriquen et al. (2016).

Table 1 Location and water depth of the sediment cores from Skirbekk et al. (2010) and Jernas et al. (2013). Data from these cores are shown in Fig. 8.

\begin{tabular}{llccc}
\hline Core ID & Core type & Latitude & Longitude & Water depth $(\mathrm{m})$ \\
\hline NP05-21MC & Multicorer & $7903.0 \mathrm{~N}$ & $1105.5 \mathrm{E}$ & 326 \\
NP05-21GC & Gravity corer & $7903.0 \mathrm{~N}$ & $1105.4 \mathrm{E}$ & 327 \\
\hline
\end{tabular}

5 and 2 Kya. This is in accordance with statistical analyses by Sejrup et al. (2016), showing different Holocene marine temperature trends in the eastern Nordic seas. Sejrup et al. (2016) found that the coldest millennium occurred prior to 5 Kya in the south-east and after 5 Kya in the nort-heast Nordic seas. This is reflected in the benthic foraminifer fauna in Kongsfjorden by a decreased 


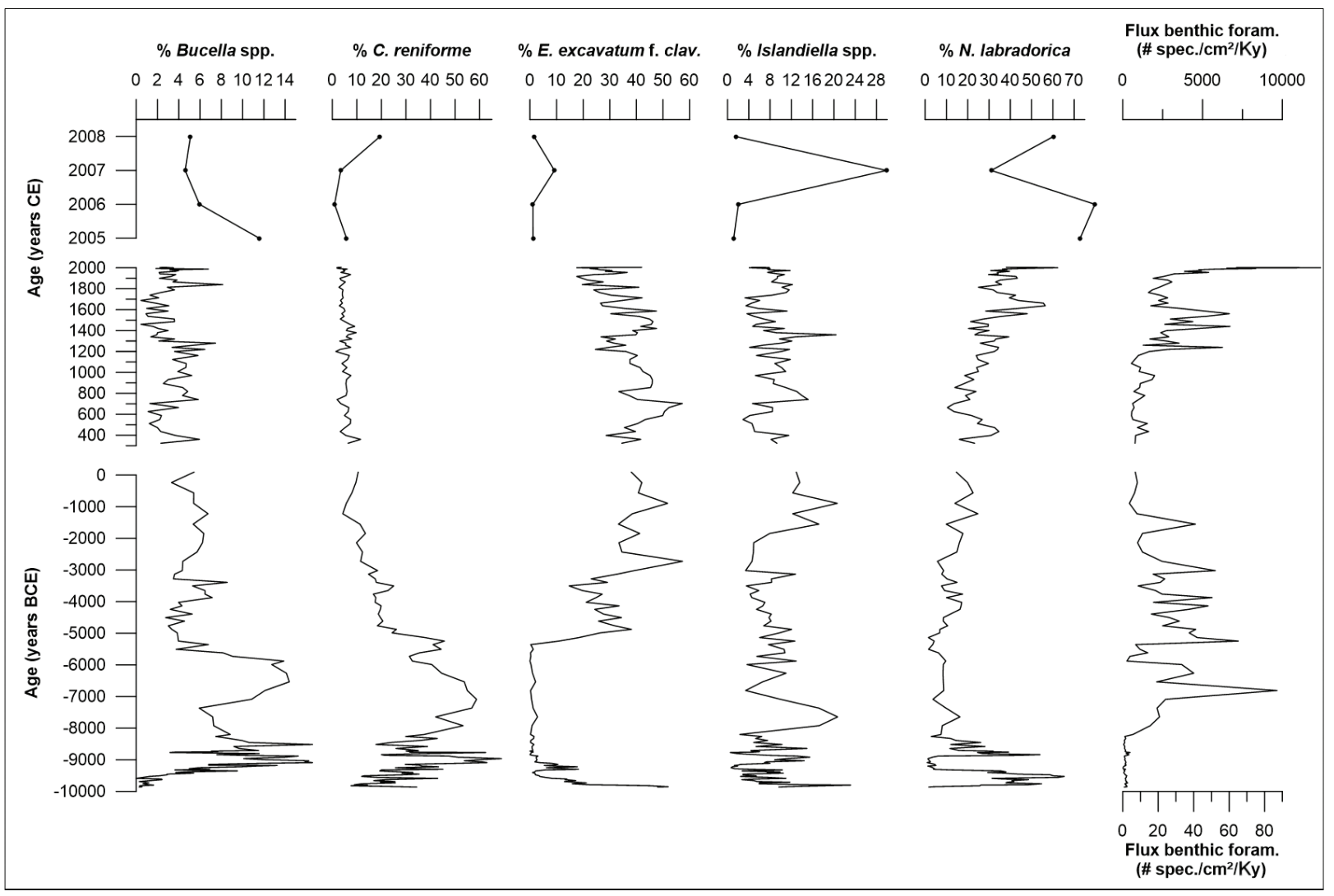

Fig. 8 Relative abundance of selected Holocene benthic foraminifera in Kongsfjorden. Note different scales on the y axis (years). Data originate from studies by Skirbekk et al. (2010), sediment core NP05-21GC (10 000-0 BCE), Jernas et al. (2013), sediment cores NP05-21 GC and NP05-21 MC (400-2000 CE), and Jernas et al. (2018), surface sediment samples from 2005 to 2008 CE.

production of benthic foraminifera and an increase of the glaciomarine species Elphidium excavatum f. clavata (Fig. 8; Skirbekk et al. 2010). This colder environment existed under enhanced glacial influence, as reflected by an elevated IRD flux (Skirbekk et al. 2010). After 2.0 Kya, conditions became unstable (Rasmussen et al. 2014). Reconstructions by Jernas et al. (2013) reveal fluctuating conditions, yet an overall warming of bottom waters at the fjord mouth of Kongsfjorden during the past two millennia as E. excavatum f. clavata decreases (Table 1, Fig. 8; Jernas et al. 2013). An enhanced inflow of AW to Kongsfjorden occurred between 700 and $1200 \mathrm{CE}$, and afterwards a highly productive oceanographic front developed near the fjord mouth from 1200 to $1500 \mathrm{CE}$ during the MCA. This period was characterized by the highest IRD flux recorded for the investigated last two millennia and can be explained mainly by enhanced glacial activity on land. During the following LIA (1500-1900 CE) AW still flowed into Kongsfjorden, but productivity was reduced (Fig. 8; Jernas et al. 2013). Jernas et al. (2013) attribute the relatively elevated IRD flux during the LIA (reduced in comparison to the MCA) to (1) limited erosion of glaciers, the trapping of icebergs within fjords owing to more permanent sea-ice cover, forcing the icebergs to release their debris in the fjords, or/and (2) cold surface waters preventing icebergs from releasing their debris before passing the core location. After $1900 \mathrm{CE}$, advection of AW and productivity increased. Investigations of the modern benthic foraminiferal fauna (Jernas et al. 2018) show additional faunal changes after the increased inflow of AW after 2005 (Cottier et al. 2007). The frequency of E. excavatum $\mathrm{f}$. clavata is strongly reduced, while the frequency of Cassidulina reniforme is low, and the benthic foraminiferal fauna is dominated by Nonionellina labradorica (Fig. 8; Jernas et al. 2018). The Buccella and Islandiella species are relatively abundant (Fig. 8). Nonionellina labradorica is characteristic of water masses with a high amount of available nutrition and high biological productivity, supporting the view of an inflow of warmer nutrient-rich waters (Jernas et al. 2018). A high-resolution study from the West Spitsbergen Slope inferred that the subsurface temperatures were relatively stable during the past two 
millennia until $1900 \mathrm{CE}$, after which time the temperatures increased markedly (Spielhagen et al. 2011). A reconstruction of summer air temperature based on lake sediments shows the same trend, with stable temperatures over a period of 1800 years and a sudden increase after 1900 CE (D'Andrea et al. 2012).

\section{Discussion and concluding remarks}

Since the last glacial, the Kongsfjorden-Krossfjorden system has gone through significant environmental change from being filled by a fast-flowing ice stream (e.g., Ottesen et al. 2007) to becoming an open fjord, still influenced by tidewater glaciers. During the early Holocene there was also a strong influence of AW in Kongsfjorden, as seen for the whole region (e.g., Hald et al. 2004; Forwick $\delta$ Vorren 2009; Baeten et al. 2010; Skirbekk et al. 2010; Rasmussen et al. 2012; Rasmussen et al. 2014; Werner et al. 2016). Both the solar forcing and the inflow of AW decreased in the mid-Holocene, resulting in a cooling and glacier growth in Svalbard (e.g., Hald et al. 2004; Forwick \& Vorren 2009; Rasmussen et al. 2012). Within the last two millennia, the glaciers on Svalbard fluctuated repeatedly. The climate events MCA and LIA were caused by several factors. One factor shaping both events was atmospheric forcing, as the North Atlantic Oscillation was in a strong positive mode during the MCA and neutral to vaguely negative during the LIA (Trouet et al. 2009). Solar and volcanic forcing (Shindell et al. 2003) also contributed to LIA cooling. The water masses in Kongsfjorden show fluctuations that seem to reflect MCA and LIA by changes in productivity and subtle faunal changes in addition to showing an overall increasing influence of AW during the past two millennia towards the present day (Jernas et al. 2013). When comparing the benthic foraminiferal fauna from the early Holocene with the modern fauna from 2006, it seems that they are, to some extent, different. The modern fauna shows a somewhat higher relative abundance of $N$. labradorica and somewhat lower abundance of $C$. reniforme compared to the fauna of the early Holocene, possibly reflecting more nutrient-rich conditions now than during the early Holocene (Fig. 8). The causes of this difference remain to be identified, and there is a need to monitor the current changes to improve the understanding of the effects of climate change on the marine environments of Svalbard fjords, for example, with regard to hydrography and glacier extent. Reconstructions of sea ice in Kongsfjorden in the past are still pending. Such reconstructions are necessary to enable comparisons between natural warm periods of the past (the early Holocene and MCA) and the modern warming. Such reconstructions can be based on the analyses of sea-ice proxies, like sea-ice diatoms (e.g., Justwan \& Koç 2008; Miettinen et al. 2015) or sea-ice biomarkers from highly branched isoprenoids (e.g., Belt \& Müller 2013; Belt et al. 2017). These modern reconstruction techniques together with ongoing studies on sediment cores taken both from inner and outer Kongsfjorden will help to improve our understanding of the ocean, sea-ice and atmosphere interactions of the area in the future.

Changes in the fjord environment due to modern warming are affecting the present-day biotic system and will likely continue to do so in the future. The increased glacier melting and sediment flux from both the glaciers and the coast into the fjord will affect the natural habitats and the ecosystem, with impacts on all trophic levels. Studies of macrozoobenthic communities by WlodarskaKowalczuk et al. (2005) and Laudien et al. (2007) have shown how iceberg scour and increased turbidity reduce the biomass and change the diversity. Kongsfjorden's glaciers are being monitored on a long-term basis (e.g., WGMS 2009; Karner et al. 2013). However, long-term studies of coastline changes in Kongsfjorden are also needed to quantify and constrain models to measure the impact of the climate warming on the whole Kongsfjorden ecosystem. Changes of glacier dynamics may also affect planktic and nektic fauna in the water column, in addition to seabirds and marine mammals (e.g., Lydersen et al. 2014 ; Urbanski et al. 2017). Hence, the current climate changes and their impacts make it imperative to increase our knowledge of climate-ocean-glacier systems. The KongsfjordenKrossfjorden system is a natural archive that provides reference values for polar marine sedimentary environments.

\section{Acknowledgements}

This study was initiated at the workshop Past Marine Sedimentary environments in the Kongsfjorden-Krossfjorden System, Svalbard: Atmosphere, Ocean and Glacier Linkages, held at the Norwegian Polar Institute, in Tromsø, 27-29 October 2015. We thank Boele Kuipers from the Norwegian Hydrographic Service for providing the bathymetric data for inner Kongsfjorden.

\section{Funding}

The Research Council of Norway funded the workshop that led to this study, through the Svalbard Science Forum (project no. 246696/E10).

\section{Disclosure statement}

The authors report no conflict of interest. 


\section{References}

Aagaard K. \& Carmack E.C. 1994. The Arctic ocean and climate: a perspective. In J. Johannessen et al. (eds.): The polar oceans and their role in shaping the global environment. Pp. 5-20, http://dx.doi/10.1029/GM085p0005. Washington, DC: American Geophysical Union.

Aagaard-Sørensen S., Husum K., Hald M. \& Knies J. 2010. Paleoceanographic development in the SW Barents Sea during the Late Weichselian-Early Holocene transition. Quaternary Science Reviews 29, 3442-3456, http://dx.doi. org/10.1016/j.quascirev.2010.08.014.

Aagaard-Sørensen S., Husum K., Hald M., Marchitto T. \& Godtliebsen F. 2014. Sub sea surface temperatures in the polar North Atlantic during the Holocene: planktic foraminiferal Mg/Ca temperature reconstructions. Holocene 24, 93-103, http://dx.doi.org/10.1 177/0959683613515730.

Baeten N.J., Forwick M., Vogt C. \& Vorren T.O. 2010. Late Weichselian and Holocene sedimentary environments and glacial activity in Billefjorden, Svalbard. In J.A. Howe et al. (eds.): Fjord systems and archives. Pp. 207-223, http://dx. doi.org/10.1 144/SP344.15. London: Geological Society.

Bartsch I., Paar M., Fredriksen S., Schwanitz M., Daniel C., Hop H. \& Wiencke C. 2016. Changes in kelp forest biomass and depth distribution in Kongsfjorden, Svalbard, between 1996-1998 and 2012-2014 reflect Arctic warming. Polar Biology 39, 2021-2036, http://dx.doi.org/10.1007/ s00300-015-1870-1.

Belt S.T., Brown T.A., Smik L., Tatarek A., Wiktor J., Stowasser G., Assmy P., Allen C.S., \& Husum K. 2017. Identification of $\mathrm{C}_{25}$ highly branched isoprenoid (HBI) alkenes in diatoms of the genus Rhizosolenia in polar and sub-polar marine phytoplankton. Organic Geochemistry 110, 65-72, http://dx.doi.org/10.1016/j.orggeochem.2017.05.007.

Belt S.T. \& Müller J. 2013. The Arctic sea ice biomarker $\mathrm{IP}_{25}$ : a review of current understanding, recommendations for future research and applications in palaeo sea ice reconstructions. Quaternary Science Reviews 79, 9-25, http://dx. doi.org/10.1016/j.quascirev.2012.12.001.

Berge J., Heggland K., Lønne O.J., Cottier F., Hop H., Gabrielsen G.W., Nøttestad L. \& Misund O.A. 2015. First records of Atlantic mackerel (Scomber scombrus) from the Svalbard Archipelago, Norway, with possible explanations for the extension of its distribution. Arctic 68, 54-61, http://dx.doi. org/10.14430/arctic4455.

Bergh S.G., Maher H.D. Jr. \& Braathen A. 2000. Tertiary divergent thrust directions from partitioned transpression, Brøggerhalvøya, Spitsbergen. Norwegian Geological Society Journal 80, 63-82, http://dx.doi.org/10.1080/ 002919600750042573.

Beszczynska-Möller A., Fahrbach E., Schauer U. \& Hansen E. 2012. Variability in Atlantic water temperature and transport at the entrance to the Arctic Ocean, 1997-2010. ICES Journal of Marine Science 69, 852-863, http://dx.doi. org/10.1093/icesjms/fss056.

Boos M. 2012. Holocene environmental changes in the European Arctic: a sediment-provenance study of glacio-marine sediments in Kongsfjorden, Svalbard. Master's thesis, Vrije Universiteit
Amsterdam, in collaboration with Norwegian Polar Institute.

Bourriquen M., Baltzer A., Mercier D., Fournier J., Pérez L., Haquin S., Bernard E. \& Jensen M. 2016. Coastal evolution and sedimentary mobility of Brøgger Peninsula, north west Spitsbergen. Polar Biology 39, 1689-1698, http://dx. doi.org/10.1007/s00300-016-1930-1.

Carmack E., Polyakov I., Padman L., Fer I., Hunke E., Hutchings J., Jackson J., Kelly D., Kwok R., Layton C., Melling H., Perovich H., Persson O., Ruddick B., Timmermans M.-L., Toole J., Ross T., Vavrus S. \& Winsor P. 2015. Toward quantifying the increasing role of oceanic heat in sea ice loss in the new Arctic. Bulletin of the American Meteorological Society 96, 2079-2105, http://dx.doi.org/10.1175/ BAMS-D-13-00177.1.

Cottier F.R., Nilsen F., Inall M.E., Gerland S., Tverberg V. \& Svendsen H. 2007. Wintertime warming of an Arctic shelf in response to large-scale atmospheric circulation. Geophysical Research Letters 34, L10607, http://dx.doi. org/10.1029/2007GL029948.

Cottier F.R., Nilsen F., Skogseth R., Tverberg V., Skarðhamar J. \& Svendsen H. 2010. Arctic fjords: a review of the oceanographic environment and dominant physical processes. In J.A. Howe et al. (eds.): Fjord systems and archives. Pp. 35-50, http://dx.doi. org/10.1144/SP344.4. London: Geological Society.

Cottier F.R., Tverberg V., Inall M., Svendsen H., Nilsen F. \& Griffiths C. 2005. Water mass modification in an Arctic fjord through cross-shelf exchange: the seasonal hydrography of Kongsfjorden, Svalbard. JournalofGeophysical Research-Oceans 110, C12005, http://dx.doi.org/10.1029/2004JC002757.

Dallmann W.K. 2015. Geoscience atlas of Svalbard. Norwegian Polar Institute Report Series 148. Tromsø: Norwegian Polar Institute.

D'Andrea W.J., Vaillencourt D.A., Balascio N.L., Werner A., Roof S.R., Retelle M. \& Bradley R.S. 2012. Mild Little Ice Age and unprecedented recent warmth in an 1800 year lake sediment record from Svalbard. Geology 40, 1007-1010, http://dx.doi.org/10.1130/G33365.1.

Dijkstra N. 2009. Sedimentation processes in two (sub-) Arctic fjord systems: a comparison of modern and Holocene sedimentation processes in Kongsfjorden (NW Svalbard) and Disko Bay (W Greenland). Master's thesis, Vrije Universiteit Amsterdam, in collaboration with Norwegian Polar Institute.

Dokken T.M. \& Hald M. 1996. Rapid climatic shifts during isotope stages $2-4$ in the polar North Atlantic. Geology 24, 599-602, http://dx.doi.org/10.1130/0091-7613(1996)024 $<0599$ :RCSDIS $>2.3$.CO; 2 .

Dowdeswell J.A., Ottesen D. \& Forwick M. 2016. Grounding-zone wedges on the western Svalbard shelf. In J.A. Dowdeswell et al. (eds.): Atlas of submarine glacial landforms: modern, Quaternary and ancient. Pp. 233-234, http://dx.doi. org/10.1 144/M46.128. London: Geological Society.

Elverhøi A., Liestøl O. \& Nagy J. 1980. Glacial erosion, sedimentation and microfauna in the inner part of Kongsfjorden, Spitsbergen. Norsk Polarinstitutt Skrifter 172, 33-61.

Elverhøi A., Lønne Ø. \& Seland R. 1983. Glaciomarine sedimentation in a modern fjord environment, Spitsbergen. Polar Research 1, 127-149, http://dx.doi.org/10.3402/polar. vli2.6978. 
Farnsworth W.R., Ingólfsson Ó., Retelle M. \& Schomacker A. 2016. Over 400 previously undocumented Svalbard surgetype glaciers identified. Geomorphology 264, 52-60, http:// dx.doi.org/10.1016/j.geomorph.2016.03.025.

Forwick M., Laberg J.S., Vorren T.O. \& Jernas P. 2015. Quaternary geology and geomorphology, fjord bathymetry and geology. In W.K. Dallmann (ed.): Geoscience atlas of Svalbard. Norwegian Polar Institute Report Series 148. Pp. 53-88. Tromsø: Norwegian Polar Institute.

Forwick M. \& Vorren T.O. 2009. Late Weichselian and Holocene sedimentary environments and ice rafting in Isfjorden, Spitsbergen. Palaeogeography Palaeoclimatology Palaeoecology 280, 258-274, http://dx.doi.org/10.1016/ j.palaeo.2009.06.026.

Gerland S. \& Renner A.H.H. 2007. Sea-ice mass-balance monitoring in an Arctic fjord. Annals of Glaciology 46, 435-442, http://dx.doi.org/10.3189/172756407782871215.

Hagen J.O., Liestøl O., Roland E. \& Jørgensen T. 1993. Glacier atlas of Svalbard and Jan Mayen. Norsk Polarinsitutt Meddelelser 129. Oslo: Norwegian Polar Institute.

Hald M., Andersson C., Ebbesen H., Jansen E., Klitgaard-Kristensen D., Risebrobakken L., Salomonsen G.R., Sarnthein M., Sejrup H.P. \& Telford R.J. 2007. Variations in temperature and extent of Atlantic Water in the northern North Atlantic during the Holocene. Quaternary Science Reviews 26, 3423-3440, http://dx.doi.org/10.1016/j. quascirev.2007.10.005.

Hald M., Ebbesen H., Forwick M., Godtliebsen F., Khomenko L., Korsun S., Olsen L.R. \& Vorren T.O. 2004. Holocene paleoceanography and glacial history of the west Spitsbergen area, Euro-Arctic margin. Quaternary Science Reviews 23, 2075-2088, http://dx.doi.org/10.1016/j. quascirev.2004.08.006.

Hald M. \& Korsun S. 2008. The 8200 cal. yr BP event reflected in the Arctic fjord, Van Mijenfjorden, Svalbard. Holocene 18, 981-990, http://dx.doi.org/10.1177/ 0959683608093536.

Hebbeln D., Dokken T., Andersen E.S., Hald M. \& Elverhøi A. 1994. Moisture supply for northern ice-sheet growth during the last glacial-maximum. Nature 370, 357-360, http://dx.doi.org/10.1038/370357a0.

Henriksen M., Alexanderson H., Landvik J.Y., Linge H. \& Peterson G. 2014. Dynamics and retreat of the Late Weichselian Kongsfjorden ice stream, NW Svalbard. Quaternary Science Reviews 92, 235-245, http://dx.doi. org/10.1016/j.quascirev.2013.10.035.

Hop H., Falk-Petersen S., Svendsen H., Kwasniewski S., Pavlov V., Pavlova O. \& Søreide J.E. 2006. Physical and biological characteristics of the pelagic system across Fram Strait to Kongsfjorden. Progress in Oceanography 71, 182-231, http://dx.doi.org/10.1016/j.pocean.2006.09.007.

Hop H., Pearson T., Hegseth E.N., Kovacs K.M., Wiencke C., Kwasniewski S., Eiane K., Mehlum F., Gulliksen B., Wlodarska-Kowalczuk M., Lydersen C., Weslawski J.M., Cochrane S., Gabrielsen G.W., Leakey R.J.G., Lønne O.J., Zajaczkowski M., Falk-Petersen S., Kendall M., Wängberg S.-Å, Bischof K., Voronkov A.Y., Kovaltchouk N.A., Wiktor J., Poltermann M., di Prisco G., Papucci C. \&
Gerland S. 2002. The marine ecosystem of Kongsfjorden, Svalbard. Polar Research 21, 167-208, http://dx.doi. org/10.3402/polar.v21il.6480.

Howe J.A., Moreton S.G., Morri C. \& Morris P. 2003. Multibeam bathymetry and the depositional environments of Kongsfjorden and Krossfjorden, western Spitsbergen, Svalbard. Polar Research 22, 301-316, http://dx.doi. org/10.1111/j.1751-8369.2003.tb00114.x.

Inall M.E., Nilsen F., Cottier F.R. \& Daae R. 2015. Shelf/fjord exchange driven by coastal-trapped waves in the Arctic. Journal of Geophysical Research-Oceans 120, 8283-8303, http://dx.doi.org/10.1002/2015JC011277.

Jernas P., Kristensen D.K., Husum K., Koç N., Tverberg V., Loubere P., Prins M., Dijkstra N. \& Głuchowska M. 2018. Annual changes in Arctic fjord environment and modern benthic foraminiferal fauna; evidence from Kongsfjorden, Svalbard. Global and Planetary Change 163, 119-140, http:// dx.doi.org/10.1016/j.gloplacha.2017.11.013.

Jernas P., Kristensen D.K., Husum K., Wilson L. \& Koç N. 2013. Palaeoenvironmental changes of the last two millennia on the western and northern Svalbard shelf. Boreas 42, 236-255, http://dx.doi.org/10.1111/j.1502-3885.2012.00293.x.

Jessen S.P., Rasmussen T.L., Nielsen T. \& Solheim A. 2010. A new Late Weichselian and Holocene marine chronology for the western Svalbard slope 30,000-0 cal years BP. Quaternary Science Reviews 29, 1301-1312, http://dx.doi. org/10.1016/j.quascirev.2010.02.020.

Justwan A. \& Koç N. 2008. A diatom based transfer function for reconstructing sea ice concentrations in the North Atlantic. Marine Micropalaeontology 66, 264-278, http://dx. doi.org/10.1016/j.marmicro.2007.11.001.

Karner F., Obleitner F., Krismer T., Kohler J. \& Greuell W. 2013. A decade of energy and mass balance investigations on the glacier Kongsvegen, Svalbard. Journal of Geophysical Research-Atmospheres 118, 3986-4000, http://dx.doi. org/10.1029/2012JD018342.

Kehrl L.M., Hawley R.L., Powell R.D. \& Brigham-Grette J. 2011 . Glacimarine sedimentation processes at Kronebreen and Kongsvegen, Svalbard. Journal of Glaciology 57, 841-847, http://dx.doi.org/10.3189/002214311798043708.

Kortsch S., Primicerio R., Beuchel F., Renaud P.E., Rodrigues J., Lønne O.J. \& Gulliksen B. 2012. Climate-driven regime shifts in Arctic marine benthos. Proceedings of the National Academy of Sciences of the United States of America 109, 14052-14057, http://dx.doi.org/10.1073/ pnas. 1207509109.

Kremer A., Stein R., Fahl K., Ji Z., Yang Z., Wiers S., Matthiessen J., Forwick M., Löwemark L., O’Regan M., Chen J. \& Snowball I. 2018. Changes in sea ice cover and ice sheet extent at the Yermak Plateau during the last 160 ka-reconstructions from biomarker records. Quaternary Science Reviews 182, 93-108, http://dx.doi.org/10.1016/j. quascirev.2017.12.016.

Kumar P., Pattanaik J.K., Khare N. \& Balakrishnan S. 2018. Geochemistry and provenance study of sediments from Krossfjorden and Kongsfjorden, Svalbard (Arctic Ocean). Polar Science 18, 72-82, http://dx.doi.org/10.1016/j. polar.2018.06.001. 
Lamb H.H. 1977. Climate, present, past and future. London: Methuen \& Co.

Landvik J.Y., Brook E.J., Gualtieri L., Linge H., Raisbeck G., Salvigsen O. \& Yiou F. 2013. ${ }^{10} \mathrm{Be}$ exposure age constraints on the Late Weichselian ice-sheet geometry and dynamics in inter-ice-stream areas, western Svalbard. Boreas 42, 43-56, http://dx.doi.org/10.1111/j. 1502-3885.2012.00282.x.

Landvik J.Y., Brook E.J., Gualtieri L., Raisbeck G., Salvigsen O. \& Yiou F. 2003. Northwest Svalbard during the last glaciation: ice-free areas existed. Geology 31, 905-908, http:// dx.doi.org/10.1130/G19703.1.

Landvik J.Y., Ingólfsson Ó., Mienert J., Lehman S.J., Solheim A., Elverhøi A. \& Ottesen D. 2005. Rethinking Late Weichselian ice-sheet dynamics in coastal NW Svalbard. Boreas 34, 7-24, http://dx.doi.org/10.1080/03009480510012809.

Laudien J., Herrmann M. \& Arntz W.E. 2007. Soft bottom species richness and diversity as a function of depth and iceberg scour in Arctic glacial Kongsfjorden (Svalbard). Polar Biology 30, 1035-1046, http://dx.doi.org/10.1007/ s00300-007-0263-5.

Lehman S.J. \& Forman S.L. 1992. Late Weichselian glacier retreat in Kongsfjorden, west Spitsbergen, Svalbard. Quaternary Research 37, 139-154, http://dx.doi.org/10.1016/ 0033-5894(92)90078-W.

Luckman A., Benn D.I., Cottier F., Bevan S., Nilsen F. \& Inall M. 2015. Calving rates at tidewater glaciers vary strongly with ocean temperature. Nature Communications 6, article no. 8566, http://dx.doi.org/10.1038/ncomms9566.

Lydersen C., Assmy P., Falk-Petersen S., Kohler J., Kovacs K.M., Reigstad M., Steen H., Strom H., Sundfjord A., Varpe O., Walczowski W., Weslawski J.M. \& Zajaczkowski M. 2014. The importance of tidewater glaciers for marine mammals and seabirds in Svalbard, Norway. Journal of Marine Systems 129, 452-471, http://dx.doi. org/10.1016/j.jmarsys.2013.09.006.

MacLachlan S.E., Howe J.A. \& Vardy M.E. 2010. Morphodynamic evolution of Kongsfjorden-Krossfjorden, Svalbard, during the Late Weichselian and Holocene. In J.A. Howe et al. (eds.): Fjord systems and archives. Pp. 195-205. London: Geological Society, http://dx.doi.org/10.1144/ SP344.14.

Mangerud J., Bondevik S., Gulliksen S., Karin Hufthammer A. \& Høisæter T. 2006. Marine ${ }^{14} \mathrm{C}$ reservoir ages for 19th century whales and molluscs from the North Atlantic. Quaternary Science Reviews 25, 3228-3245, http://dx.doi. org/10.1016/j.quascirev.2006.03.010.

Meslard F., Bourrin F., Many G. \& Kerhervé P. 2018. Suspended particle dynamics and fluxes in an Arctic fjord (Kongsfjorden, Svalbard). Estuarine, Coastal and Shelf Science 204, 212-224, http://dx.doi.org/10.1016/j. ecss.2018.02.020.

Miettinen A., Divine D., Husum K., Koç N. \& Jennings A. 2015. Exceptional ocean surface conditions on the SE Greenland shelf during the Medieval Climate Anomaly. Palaeoceanography 30, 1675-1674, http://dx.doi. org/10.1002/2015PA002849.
Nilsen F., Skogseth R., Vaardal-Lunde J. \& Inall M. 2016. A simple shelf circulation model: intrusion of Atlantic Water on the West Spitsbergen Shelf. Journal of Physical Oceanography 46, 1209-1230, http://dx.doi.org/10.1175/ JPO-D-15-0058.1.

Ottesen D. \& Dowdeswell J.A. 2009. An inter-ice-stream glaciated margIn: submarine landforms and a geomorphic model based on marine-geophysical data from Svalbard. Geological Society of America Bulletin 121, 1647-1665, http:// dx.doi.org/10.1130/B26467.1.

Ottesen D., Dowdeswell J.A., Landvik J.Y. \& Mienert J. 2007. Dynamics of the Late Weichselian ice sheet on Svalbard inferred from high-resolution seafloor morphology. Boreas 36, 286-306, http://dx.doi. org/10.1080/03009480701210378.

Ottesen D., Dowdeswell J.A. \& Rise L. 2005. Submarine landforms and the reconstruction of fast-flowing ice streams within a large Quaternary ice sheet: the 2500-km-long Norwegian-Svalbard margin $\left(57^{\circ}-80^{\circ} \mathrm{N}\right)$. Geological Society of America Bulletin 117, 1033-1050, http://dx.doi.org/ 10.1130/B25577.1.

Pawłowska J., Zajączkowski M., Łącka M., Lejzerowicz F., Esling P. \& Pawlowski J. 2016. Palaeoceanographic changes in Hornsund fjord (Spitsbergen, Svalbard) over the last millennium: new insights from ancient DNA. Climate of the Past 12, 1459-1472, http://dx.doi.org/10.5194/ cp-12-1459-2016.

Polyakov I.V., Pnyushkov A.V., Alkire M.B., Ashik I.M., Baumann T.M., Carmack E.C., Goszczko I., Guthrie J., Ivanov V.V., Kanzow T., Krishfield R., Kwok R., Sundfjord A., Morison J., Rember R. \& Yulin A. 2017. Greater role for Atlantic inflows on sea-ice loss in the Eurasian Basin of the Arctic Ocean. Science 356, 285-291, http://dx.doi. org/10.1126/science.aai8204.

Ramsey B.C. 2009. Bayesian analysis of radiocarbon dates. Radiocarbon 51, 337-360, http://dx.doi.org/10.1017/ S0033822200033865.

Rasmussen T.L., Forwick M. \& Mackensen A. 2012. Reconstruction of inflow of Atlantic Water to Isfjorden, Svalbard during the Holocene: correlation to climate and seasonality. Marine Micropaleontology 94/95, 80-90, http://dx.doi. org/10.1016/j.marmicro.2012.06.008.

Rasmussen T.L., Thomsen E., Skirbekk K., Ślubowska-Woldengen M., Klitgaard Kristensen D. \& Koç N. 2014. Spatial and temporal distribution of Holocene temperature maxima in the northern Nordic seas: interplay of Atlantic-, Arctic- and polar water masses. Quaternary Science Reviews 92, 280-291, http://dx.doi.org/10.1016/j. quascirev.2013.10.034.

Reimer P.J., Baillie M.G.L., Bard E., Bayliss A., Beck J.W., Blackwell P.G., Ramsey C.B., Buck C.E., Burr G.S., Edwards R.L., Friedrich M., Grootes P.M., Guilderson T.P., Hajdas I., Heaton T.J., Hogg A.G., Hughen K.A., Kaiser K.F., Kromer B., McCormac F.G., Manning S.W., Reimer R.W., Richards D.A., Southon J.R., Talamo S., Turney C.S.M., van der Plicht J. \& Weyhenmeye C.E. 2009. INTCAL09 and MARINE09 radiocarbon age calibration curves, 
0-50,000 years cal BP. Radiocarbon 51, 1111-1150, http:// dx.doi.org/10.1017/S0033822200034202.

Richter-Menge J., Overland J.E., Mathis J.T. \& Osborne E. 2017. Arctic Report Card 2017. Silver Spring, MD: National Oceanic and Atmospheric Administration.

Risebrobakken B., Dokken T., Smedsrud L.H., Andersson C., Jansen E., Moros M. \& Ivanova E.V. 2011. Early Holocene temperature variability in the Nordic seas: the role of oceanic heat advection versus changes in orbital forcing. Palaeoceanography 26, PA4206, http://dx.doi. org/10.1029/2011PA002117.

Rudels B., Jones, E.P., Anderson L.G. \& Kattner G. 1994. On the intermediate depth waters of the Arctic Ocean. In O.M. Johannessen et al. (eds.): The polar oceans and their role in shaping the global environment. Pp. 33-46, http://dx. doi/10.1029/GM085p0033. Washington, DC: American Geophysical Union.

Schauer U., Fahrbach E., Osterhus S. \& Rohardt G. 2004. Arctic warming through the Fram Strait: oceanic heat transport from 3 years of measurements. Journal of Geophysical Research-Oceans 109, C06026, http://dx.doi. org/10.1029/2003JC001823.

Sejrup H.P., Seppa H., McKay N.P., Kaufman D.S., Geirsdottir A., de Vernal A., Renssen H., Husum K., Jennings A. \& Andrews J.T. 2016. North AtlanticFennoscandian Holocene climate trends and mechanisms. Quaternary Science Reviews 147, 365-378, http://dx.doi. org/10.1016/j.quascirev.2016.06.005.

Sexton D.J., Dowdeswell J.A., Solheim A. \& Elverhøi A. 1992. Seismic architecture and sedimentation in northwest Spitsbergen fjords. Marine Geology 103, 53-68, http:// dx.doi/10.1016/0025-3227(92)90008-6.

Shindell D.T., Schmidt G.A., Miller R.L. \& Mann M.E. 2003. Volcanic and solar forcing of climate change during the preindustrial era. Journal of Climate 16, 4094-4107, http://dx.doi.org/10.1175/1520-0442(2003)016<4094 :VASFOC $>2.0 . \mathrm{CO} ; 2$

Skirbekk K., Klitgaard Kristensen D., Rasmussen T.L., Koç N. \& Forwick M. 2010. Holocene climate variations at the entrance to a warm Arctic fjord: evidence from Kongsfjorden trough, Svalbard. In J.A. Howe et al. (eds.): Fjord systems and archives. Pp. 289-304, http://dx.doi. org/10.1144/SP344.20. London: Geological Society.

Ślubowska M.A., Koç N., Rasmussen T.L. \& Klitgaard-Kristensen D. 2005. Changes in the flow of Atlantic water into the Arctic Ocean since the last deglaciation: evidence from the northern Svalbard continental margin, $80^{\circ}$ N. Palaeoceanography 20, PA4014, http://dx.doi. org/10.1029/2005PA001141.

Spielhagen R.F., Werner K., Sørensen S.A., Zamelczyk K., Kandiano E., Budeus G., Husum K., Marchitto T.M. \& Hald M. 2011 . Enhanced modern heat transfer to the Arctic by warm Atlantic Water. Science 331, 450-453, http:// dx.doi.org/10.1126/science.1197397.

Sternal B., Szczuciński W., Forwick M., Zajączkowski M., Lorenc S. \& Przytarska J. 2014. Postglacial variability in near-bottom current speed on the continental shelf off south-west Spitsbergen. Journal of Quaternary Science 29, 767-777, http://dx.doi.org/10.1002/jqs.2748.

Streuff K., Forwick M., Szczuciński W., Andreassen K. \& Ó Cofaigh C. 2015. Submarine landform assemblages and sedimentary processes related to glacier surging in Kongsfjorden, Svalbard. Arktos 1, article no. 14, http://dx.doi. org/10.1007/s41063-015-0003-y.

Stuiver M. \& Reimer P.J. 1993. Extended ${ }^{14} \mathrm{C}$ data base and revised CALIB $3.0{ }^{14} \mathrm{C}$ age calibration program. Radiocarbon 35, 215-230, http://dx.doi.org/10.1017/ S0033822200013904.

Sundfjord A., Albretsen J., Kasajima Y., Skogseth R., Kohler J., Nuth C., Skarðhamar J., Cottier F., Nilsen F., Asplin L., Gerland S. \& Torsvik T. 2017. Effects of glacier runoff and wind on surface layer dynamics and Atlantic Water exchange in Kongsfjorden, Svalbard; a model study. Estuarine, Coastal and Shelf Science 187, 260-272, http://dx. doi.org/10.1016/j.ecss.2017.01.015.

Svendsen H., Beszczynska-Møller A., Hagen J.O., Lefauconnier B., Tverberg V., Gerland S., Ørbæk J.B., Bischof K., Papucci C., Zajaczkowski M., Azzolini R., Bruland O., Wiencke C., Winther J.G. \& Dallmann W. 2002. The physical environment of Kongsfjorden-Krossfjorden, an Arctic fjord system in Svalbard. Polar Research 21, 133-166, http://dx.doi.org/10.1111/j.1751-8369.2002. tb00072.x.

Szczuciński W., Zajączkowski M. \& Scholten J. 2009. Sediment accumulation rates in subpolar fjords-impact of post-Little Ice Age glaciers retreat, Billefjorden, Svalbard. Estuarine, Coastal and Shelf Science 85, 345-356, http://dx. doi.org/10.1016/j.ecss.2009.08.021.

Trouet V., Esper J., Graham N.E., Baker A., Scourse J.D. \& Frank D.C. 2009. Persistent positive North Atlantic Oscillation mode dominated the Medieval Climate Anomaly. Science 324, 78-80, http://dx.doi.org/10.1126/ science.1166349.

Trusel L.D., Powell R.D., Cumpston R.M. \& Brigham-Grette J. 2010. Modern glacimarine processes and potential future behaviour of Kronebreen and Kongsvegen polythermal tidewater glaciers, Kongsfjorden, Svalbard. In J.A. Howe et al. (eds.): Fjord systems and archives. Pp. 89-102, http://dx.doi.org/10.1144/SP344.9. London: Geological Society.

Tverberg V. \& Nøst O.A. 2009. Eddy overturning across a shelf edge front: Kongsfjorden, west Spitsbergen. Journal of Geophysical Research-Oceans 114, C04024, http://dx.doi. org/10.1029/2008JC005106.

Urbanski J.A., Stempniewicz L., Węsławski J.M., Dragańska-Deja K., Wochna A., Goc M. \& Iliszko L. 2017. Subglacial discharges create fluctuating foraging hotspots for sea birds in tidewater glacier bays. Nature Scientific Reports 7, article no. 43999, http://dx.doi.org/10.1038/srep43999. Walczowski W., Piechura J., Goszczko I. \& Wieczorek P. 2012. Changes in Atlantic Water properties: an important factor in the European Arctic marine climate. ICES Journal of Marine Science 69, 864-869, http://dx.doi/10.1093/ icesjms/fss068. 
Werner K., Müller J., Husum K., Spielhagen R.F., Kandiano E.S. \& Polyak L. 2016. Holocene sea subsurface and surface water masses in the Fram Strait-comparisons of temperature and sea-ice reconstructions. Quaternary Science Reviews 147, 194-209, http://dx.doi.org/10.1016/j. quascirev.2015.09.007.

WGMS 2009. Glacier mass balance bulletin no. 10 (2006-2007). W. Haeberli et al. (eds.). Zürich: World Glacier Monitoring Service.
Wiencke C. \& Hop H. 2016. Ecosystem Kongsfjorden: new views after more than a decade of research. Polar Biology 39, 1679-1687, http://dx.doi.org/10.1007/ s00300-016-2032-9.

Wlodarska-Kowalczuk M., Pearson T.H. \& Kendall M.A. 2005. Benthic response to chronic natural physical disturbance by glacial sedimentation in an Arctic fjord. Marine Ecology Progress Series 303, 31-41, http://dx.doi. org/10.3354/meps303031. 